\title{
The Factor of Unwillingness to Communicate English: Focusing on The Anxiety in Speaking
}

\author{
Pebriani Kella ${ }^{1}$ \\ 1,2 Department of English Language Studies, Universitas Hasanuddin, Makassar, Indonesia \\ *pebrianikella10@gmail.com
}

\begin{abstract}
The purpose of this study is to know about the effect in the unwillingness to communicate. Especially factor anxiety to speaking English, this study used the qualitative method that used the approach descriptive research. This study analysed the phenomena and the issue which is the problem of students in linguistic class that they are still anxious to speak in class. The population the research took was random by different high levels in a class total of 10 students and the sample by the research were 10 students to answer 'agree or disagree' statements about their opinion in anxiety speaking, the research makes an instrument adopted FLCAS (Foreign Language Classroom Anxiety Scale). This study collected the data by using Google Form, and the data was divided into two steps: the first questioner and the second is the interview. This result showed that most students have little anxiety about speaking English in class.
\end{abstract}

Key words: Anxiety, factor, speaking.

\section{Introduction}

The fundamentals of Foreign language is Communicating. Communication plays a significant role in people's lives in which they use communication with their families, friends, and other people. Moreover, communication is more meaningful between teachers and students in class. With communication, we know all the aspects of each other like business, culture, and education. Communication is important to effective skills in the qualification, which is that the culture can change the society to learn multiplication language, like the increased ability of students to communicate between cultures. [1]. Language and connection to learn the language in the world. With available communication, people can make relations with other people in the world [2]. However, in people's lives communication is used every day as a tool for communication with others. On the other hand, communication has a good role in various aspects, which is education where a teacher can communicate with students in class. the same as a purpose in education as to how the student speaks the language to become effective, including connecting classmates, large class and the situation class [3].

In learning a language, communication is very important. Students have that skill to influence the process of student communication in the second language. By this there one of the purposes is knowing what factors can influence the student learning English. According to Zeng, there are some influences that are found; the classroom, teacher sport, student confidence [4]. Lee and Hsieh stated that there are some factors that can improve student 
communication which include classroom involvement, motivation and patience [5]. However, there are some found that there are students who still have to communicate with people or not speak in class. In this era, most students still have the attitude to not communicate with their friends in class, which is caused by some factors like nervousness, or afraid to communicate.

Al-Murtadha \& Feryok said that when students learn English, there are two things they communicate [6]. The first is the student has the motivation to speak and also the second student does not have the motivation that means they just silent or disappear when the teacher gives the opportunity to communicate in class, Adding by Fukuta, two communications are when a student chooses to not communicate their call is UWTC, and the second is the student has a willingness to communication call is WTC [7]. One the issue in teachers is students have the willingness and unwillingness to communicate in English foreign language (EFL ) in the classroom like they said that that is inclusive of influence by study and a feat in student learning English unwillingness to communicate and then Zarrinabadi conducted the study about willingness to communicate [8]. He found the student difficult to explain their knowledge to the second language, things that affected the student not comfortable, or, the topic is unfamiliar, the size they did not have an interlocutor to support their communication as second language. Then the circle can also influence factors of unwillingness to communicate, in the things in communication-related with how well we speak to convey the message to people. With a good speaker, someone can understand what they said, but sometimes someone or student feels scared about communication in foreign language, particularly speaking they have some detention in themselves or unwillingness to communicate with others. In most of Asia learning a second language or foreign language. the students seldom describe something pasif that make them unwillingness to communication English foreign language in class.[8]

\section{Theoritical Reviews}

Generally, students can understand speaking because of some factors like less vocabulary, bad grammar, a low level of speaking, and they are also scared about their intonation and pronunciation [8]. Based on students' influence of sociology like their confidence and also shyness. The thing makes the student not have spoken FL. Other research previous about anxiety, Yong divided the anxiety to six-part is anxiety with personal and interpersonal, connecting teacher and student, believe teacher about language and the true student about learning English, and test [9]. Related to learning to speak English with students and teachers to make communication, that is affected by their anxiety influenced by the behavior someone is an instruction like angry or most of the student have stressed. one anxiety release is afraid to include failure to speak English or their fear of the negative teacher. Moreover, Prince [10] found the research, anxiety language like a student has doubtful, angry and a low personal according to oxford same explain other the happen phenomena to anxiety about behavior is like student restless or student not attendance in class and also student make reaction physical such as worry or headache and stress. [10]

According to Cao, a factor that influences the student to contribute to WTC is the background culture of the student, the student is shy [11]. Their overall factor includes the atmosphere class. Worde claimed that in students there is anxiety in some phenomena like the phenomena physical like heading clammy hands cold fingers, such as grumble and rhyme heart tear have research about the factor anxiety about for 98 students from class language [12]. During the research, he found some obstacles in English foreigner such as a low to practice, and the vocabulary limited, the high a low masterly, then student little understand, afraid to do mistakes, less a ready, bad grammar a low the ability to connect to subject, they're also scared about some taunting their friends. Likewise other things influence student unwillingness divide to three steps are effective factors like students not have motivation, anxiety, and personality traits environment factors such as class size, classroom atmosphere classmate and teacher and also a teacher-related factor as topic familiarity, topic interest, attitude, support and instruction and in this paper the researcher purpose is how to know the effect anxiety to cause the student a low to speak in senior high school that focuses on class linguistic where is focus on students unwillingness comunicatication especially anxiety speaking a foreign language. The student can express themselves fluently, and not have focus attendance, and less relation involvement and family to recognize language English, the fact language is not language mother. Krashen argued that the effect of a student that has anxiety is there cannot learning English well, and adding their factor that detains to prose learning, likewise there cannot develop to study English [13].

\section{Methodology}

This study used a descriptive qualitative method. The descriptive method analyzes the phenomena and issues of students in the linguistic class [14]. The method descriptive with approach qualitative describes the deep phoneme knowledge about the information that sees the issue in subject one aspect. The population the research takes is random by different high levels in senior high school, a total of 10 students. and the sample by the research is 10 students to agree on disagree statements about their opinion in anxiety speaking, the research makes an instrument adopted by Horwitz of FLCAS (Foreign Language Classroom Anxiety Scale) [16]. This study collects the data divided 
Table 1. FLCAS (Foreigner Language Classroom Anxiety Scale)

\begin{tabular}{|c|c|c|c|c|c|c|}
\hline \multirow[b]{2}{*}{ No } & \multirow[b]{2}{*}{ Question } & \multicolumn{5}{|c|}{ Answer } \\
\hline & & SD & $\mathrm{D}$ & $\mathrm{N}$ & A & SA \\
\hline 1 & I never feel quite sure of myself when I am speaking English & & & & & \\
\hline 2 & I tremble when I know that I am going to be called on in Speech class. & & & & & \\
\hline 3 & It frightens me when I don't understand what the teacher is saying in the foreign language & & & & & \\
\hline 4 & I start to panic when I have to speak without preparation in speech class. & & & & & \\
\hline 5 & worry about the consequences of failing my Speech class & & & & & \\
\hline 6 & Speech class I feel really worried so; I forgot all the things about the material & & & & & \\
\hline 7 & I feel ashamed when I have to answer the question voluntarily at Speech class & & & & & \\
\hline 8 & I am not worried about making mistakes in Speech class & & & & & \\
\hline 9 & In Speech class, I feel so nervous and forget all the things I know & & & & & \\
\hline 10 & I would not be nervous speaking English with native speakers & & & & & \\
\hline 11 & Would not be nervous speaking English with native speakers & & & & & \\
\hline 12 & I feel the confidence to speak in Speech class & & & & & \\
\hline
\end{tabular}

Table 2. Result from Questionnaire

\begin{tabular}{lcl}
\hline Participants & Total & Level \\
\hline 1 & 39 & Low \\
2 & 36 & Low \\
3 & 47 & Medium \\
4 & 23 & Low \\
5 & 45 & Medium \\
6 & 43 & Medium \\
7 & 33 & Low \\
8 & 57 & High \\
9 & 40 & Medium \\
10 & 50 & High \\
\hline
\end{tabular}

into two steps: the first questioner and the second is the interview, the researcher collects the data by google form as a data questionnaire, and the data interview using the google form. There are 12 questions and 3 interviews for the purpose of the research to know the study oft anxiety speaking in class.

\section{Findings and Discussion}

Based on the data analysis and the questioner given, students' anxiety in speaking can be seen as follows:

In table 2, some are students that have low, high, and medium to anxiety speaking which is affected by language and psychology. Such as some students that have low anxiety speaking, like in the participants with numbers $1,2,4,7$ have anxiety to speak in language. Such as shortcoming vocabularies, lack of grammatical competence, poor pronunciation.the difference with another number that has anxiety like on the numbers 3,5,6,8,10 have high and medium on the speak. In research, the study found students' anxiety is influenced by some causes to speak English that means the acceptance by psychological. There are some factors that influence speaking English class linguistic are student little bit confident, and they are mostly if speak afraid they much think about grammar that made they're not want to speak and also their nervous. For example, if they speak, they think my speech is clear or not, because they do not want to speak English. Also, they did little have brave to communicate especially speak English the other factor is the anxiety in class is they worry and minim vocabulary to make sentences, due to he scared to make mistakes in speaking English.

After analyzing the questioner, move to analysis about interview student about anxiety speaking, and this the research showed most students fear to communicate specific speak English, such as they did not have proper speak and they not have great of vocabulary, grammar, then they worry afraid would other students not understand what they said, and also afraid to make mistake to pronunciation for speaking, then another effect by anxiety is if not have confidence if somebody correct they grammar di the class, the thing make they down to speak, and then if they are speaking they also think much about grammar.

This research tries to find the issue of students who are unwilling to communicate specifically and, on the research, make the study about giving their questioner and make an interview to know more depth about student problems. Even though the research found some effects of student unwillingness to communicate like have anxiety for speak, they did not have confidence also afford to make mistake, they don't know what they said to use English as communication, also their low vocabulary is enough, less motivation, there did not know how to make sentences to be right. These things are an obstacle for student development to learning English. Anxiety language has two 
methods to identify the first method is to show that anxiety can influence fundamentals that include situational such as social and condition life [15]. The second is when students who have anxiety can be affected by condition learning in the class. The table explains that there are some effects negative that can influence communication in the students of anxiety, the students get a low score have anxiety, by their cause of high afraid to communication, like in number 1,2,4,7 low to speak, which cause some factor. In the end, the negative effect of the thing in negative is anxiety students speak English.

\section{Conclusion}

Anxiety is one obstacle for students learning a language in which as bridge communication with other people especially in speak foreign language, and in things there some factor that makes students not have unwillingness communication is students have anxiety. particularly in senior high school where some students unwillingly communicate in a foreign language. They felt it hard to learn a foreign language, like a student with poor vocab and pronunciation, afraid grammar competence also doesn't have the motivation or student not have confidence, and this makes students unable to develop to learning the foreign language especially learning English, in other hand students have high anxiety. Besides that, teachers have a new method in losing anxiety students to learning a foreign language. With the away students not felt boring or worried about the communication especially speaking and also student more develop to study English without anxiety or worries about some factor that makes them do not communication especially speaking a foreign language

\section{References}

[1] A. Hamouda. (November 2012). "An exploring of cause of Saudi students reluctant to participate in the English language classroom" [online]. Vol 1, issue 1 pp 1-34. Available https://doi.org/10.5296/ijele.v1i1.2652

[2] A.C. Alwasilah, Pokok Kualitatif : Dasar-Dasar merancang dan melakukan penelitian kualitatif . Jakarta : kiblat Utama, 2008

[3] M. Byram, Teaching and Assessing Intercultural Communicative Competence: Revisited, $2^{\text {nd }}$ ed. Multilingual Matters, 2020.

[4] M. Zeng, “Chinese Students' Willingness to Communicate in English in Canada', Ph.D. dissertation., Depart. Educ, University of Windsor, 2010.

[5] J. S. Lee, J. C. Hsieh, "Affective variables and willingness to communicate of EFL learners in in-class, out-of-class, and digital contexts" Elsevier. Vol. 82, pp. 63-73, June 2019

[6] M. A. Murtadha and A. Feryok, "Studying English in Yemen: Situated Unwillingness to Communicate in Sociohistorical Time", Innovation in Language Learning and Teaching, vol. 11, pp. 1 - 11, April 2017.

[7] J. Fukuta, "Psychological attributes of unwillingness to communicate and task-based instruction", The Electronic Journal for English as a Second Language, vol. 21(3), 1-11, December 2018

[8] N. Zarrinabadi, S. Ketabi, and R. Abdi, "Facilitating Willingness to Communicate in the Second Language Classroom and Beyond", The Clearing House: A Journal of Educational Strategies, Issues and Ideas, vol. 87 (5) pp. 213-217, 2014 .

[9] D. J. Young, "Factors Associated with Foreign Language and Anxiety", Applied Psycholinguistics, vol. 20 (2), pp. 217-239, June 1999.

[10] M. Price, "The Subjective Experience of Foreign Language Anxiety: Interviews with Highly Anxious Students", In Language Anxiety: From Theory and Research to Classroom Implications, edited by E. Horwietz and D. Young, pp. 101-108, 1991.

[11] Y. Cao, "A Sociocognitive Perspective on Second Language Classroom Willingness to Communicate," Telos Quarterly, vol. 48 (4), pp. 789-814, December 2014.

[12] R. V. Worde, "Students' Perspectives on Foreign Language Anxiety”, Inquiry, vol. 8 (1), pp. 1-15, January 2003.

[13] S. Krashen, The Input Hypothesis: Issue and Implications, Oxford: Pergamon Press, 1985.

[14] Savigno, Communicative Language Teaching: Strategies And Goals, $1^{\text {st }}$ ed. E. Hinkel : New York, 2005

[15] E. K. Horwitz, B. Mikael, and J. Cope, "A Foreign Language Classroom Anxiety", The Modern Language Journal, vol. 70 (2), pp. 125-132, 1986. 
[16] N. Rurangwa. 'Translating Rwandan folktales into English: A culture-analysis", Thesis Dissertation.PhD Faculty of Humanities, School of Literature and Language (Translation and Interpreting Studies), 2005

[17] M.H. Arbuthnot, "Children and Books", 3 rd ed. Chicago: Scott, Foresman \& Company, 1964

[18] M.S. Hornby , Translation Studies: An Integrated Approach Amsterdam. Philadelphia: John Benjamins, 1988

[19] R. Gusnetti, S. Isnanda, et.al., "Struktur dan nilai-nilai pendidikan dalam cerita rakyat Kabupaten tanah datar Provinsi Sumatera Barat", JURNAL GRAMATIKA Jurnal Penelitian Bahasa dan Sastra Indonesia V1.i2, (183-192), 2015 